ISSN 2413-0877 Volume 2 (2015) 496

The 3rd International Conference on Biological Science 2013

(The 3rd ICBS-2013)

\title{
IMMUNOGLOBULIN-G ANTI-Toxoplasma gondii ANTIBODIES CONCENTRATION IN PERIPHERAL BLOOD SAMPLES AMONG MALE COMMERCIAL SEX WORKER IN SURAKARTA
}

\author{
Tenri Ashari Wanahari', Paramasari Dirgahayu ${ }^{1,2}$, Yulia Sari ${ }^{1,2}$, Afiono Agung Prasetyo ${ }^{1,3}$, \\ Seiji Kageyama ${ }^{4}$, Murkati ${ }^{2}$, Ruben Dharmawan ${ }^{2}$, and Asmarani Kusumawati ${ }^{5}$ \\ ${ }^{1}$ Biomedical Laboratory, Faculty of Medicine, Sebelas Maret University, Indonesia. \\ ${ }^{2}$ Department of Parasitology and Mycology, Faculty of Medicine, Sebelas Maret University, Indonesia. \\ ${ }^{3}$ Department of Microbiology, Faculty of Medicine, Sebelas Maret University, Indonesia. \\ ${ }^{4}$ Department of Microbiology, School of Medicine, Tottori University, Japan. \\ ${ }^{5}$ Center of Biotechnology Study, Gadjah Mada University, Indonesia. \\ e-mail : tenriashari@gmail.com
}

\begin{abstract}
Primary prevention of Toxoplasma gondii (T. gondii) infection among high risk-community of HIV transmission is very essential. The goal of the study was as preliminary study to quantify Immunoglobulin-G (IgG) anti-T. gondiprotein concentration in peripheral blood samples among male CSW in Surakarta, Indonesia. In cross sectional study, peripheral blood samples of thirty male CSW in Surakarta were collected, and determined for IgG anti-T. gondii using commercial enzyme-linked immunosorbent assay (ELISA) kit. Then we conducted three statistical modeling approach using simple linear regression model, to predict the IgG protein concentration $(Y)$ from each $\lg G$ index measurement $(X)$. IgG index measurement was determined by dividing samples optical density (O.D) and cut-off calibrator O.D (O.D was measured in spectrophotometer). The models were $Y_{1}=21.3^{*} X_{1}-4.3$ (for the range between 0.2 to 1.7 of $\lg G$ index), $Y_{2}=85.0^{*} X_{2}-112.5$ (between 1.7 to 2.5 of $\lg G$ index), and $Y_{3}=666.7^{*} X_{3}-1566.7$ (for more than 2.5 of $\lg G$ index). Pearson correlation analysis was used to measure relationship between $\lg G$ antibodies concentration and age ( $p$ $<0.05$ was considered as significant). All data analysis was done using STATA® 12 statistical software and Python ${ }^{8} 3.3$ programming software. The result showed that by fitting linear regression model, we found high titer (more than $300 \mathrm{IU} / \mathrm{ml}$ ) of IgG anti-T.gondii among $20 \%$ of male CSW. About $13.33 \%$ of them had moderate titer $100-300 \mathrm{IU} / \mathrm{ml}$ of $\mathrm{IgG}$ antibodies, and $66.67 \%$ of them had less than $100 \mathrm{IU} / \mathrm{ml}$ of $\mathrm{IgG}$ antibodies titer. There was mild negative correlation between IgG antibodies titers with age, but it was not significant. The present study was the first finding reported IgG anti-T. gondii concentration status among male commercial sex worker in Indonesia, indicating of a need more public health promotion for primary prevention of toxoplasmosis among this community.
\end{abstract}

Key words: Immunoglobulin-G concentration, Toxoplasma gondii, Male commercial sex worker, Indonesia, Linear regression

ISSN 2413-0877 (C) 2015 The Authors.

Published by KnowledgeE Publishing Services This is an open access article under the CC BY-NC-ND license (http://creativecommons.org/licenses/by-nc-nd/4.0)

Selection and Peer-review under responsibility of the 3rd ICBS-2013

Doi http://dx.doi.org/10.18502/kls.v2i1.201 